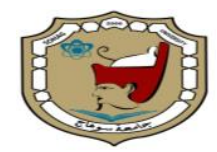

Sohag University

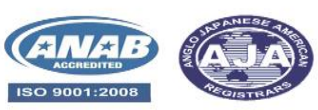

Sohag Medical Journal

Faculty of Medicine

\title{
Safety practice in Otolaryngology
}

\author{
Khaled Dahy, Ahmed Ismail, Khaled Ali.
}

Department of Otolaryngology-Head and Neck Surgery, Sohag University, Sohag, Egypt

\begin{abstract}
Background: Coronavirus disease 2019 (COVID-19) has been considered the most important public health issue recently as announced by the World Health Organization (WHO).

An otolaryngological examination made the otolaryngologists at a close relationship with the patients and hence increased risk of infection. The objective of this study is to assess the infection control measures among otorhinolaryngologists in Upper Egypt and the common symptoms of COVID they faced during practice.

Methods: A survey of 205 participants was included in the study by an internet-based questionnaire that was administered to otorhinolaryngologists of Upper Egypt.

Results: $99 \%$ of the participants faced cases of COVID-19 in their practice with $62.4 \%$ of cases presented by sudden anosmia. Infection control measures followed by $93.7 \%$ of participants with 71.2\% used a combination of face mask, alcohol, and face shield in their practice. About $53.7 \%$ of the participants do emergent surgeries with $51.7 \%$ planning to stop practice temporarily.

Conclusion: Sudden anosmia in asymptomatic patients should be taken cautiously as it may be a sign of mild attack of COVID-19 In order to decrease COVID-19 transmission among otorhinolaryngologists, infection control measures should be used appropriately for their safety.
\end{abstract}

Keywords: Anosmia, Coronavirus, COVID-19, Infection control.

\section{Introduction:}

At the end of 2019, Severe Acute Respiratory Syndrome Coronavirus 2 (SARS$\mathrm{CoV}-2$ ), was first reported as the cause of a large number of lower respi-rectory tract infections in Wuhan, China. After that, it was officially termed "COVID19" by WHO in February2020. Coronavirus disease (COVID-19) has rapidly emerged as a global health threat [1]. COVID-19 is highly contagious and considered as a Public Health Emergency of International Concern in January 2020 and a pandemic in March 2020. On July 7, 2020, a total of 11.3 million confirmed cases of COVID19 and 544.000 deaths were reported worldwide by WHO [2]. Human to human transmission either by droplets or by direct contact with secreti-ons from infected cases with many cases being asymptomatic carriers [3].

Close proximity with patients during direct otorhinolaryngological examination poses a great infectious risk to otorhinolaryngologists because droplets from a cough or sneeze can travel up to six feet [4]. Moreover, anosmia could be the first presenting symptom of COVID19, before the appearance of other symptoms such as cough and fever and this is should be taken into consideration [5]. 
The American Academy of Otolaryngology-Head and Neck Surgery's (AAO-HNS) has issued an alert advising otorhinolaryngologists to wear personal protective equipment (PPE) includes FF3/N95 mask, gloves, gown, eye protection, and a cap especially when seeing anosmia patients with respiratory symptoms and a history of international travel [6].

Thus, this study aimed to assess the infection control measures among otorhinolaryngologists in Upper Egypt and the common symptoms of COVID they faced during practice.

\section{Methodology:}

A cross-sectional study was conducted among Upper Egypt otorhinolaryngologists in June 2020. Ethical considerations were followed according to the Declaration of Helsinki. 205 participants included in this study consisted of residents, specialists, consultants, assistant professors, senior lecturers, associate professors, and professors from nearly all medical health organizations in Upper Egypt.

An internet-based questionnaire survey was designed (Table 1) consisted of 10 separate questions that audit if they faced a case of COVID-19 in their practice?, common manifestation they faced?, If they followed all instructions of infection control in their practice? What will they do if faced with a case of COVID-19 in their practice? If they regulated patients' times to avoid crowdedness? If the patients followed the instructions?, What about their surgeries?, What type of safety measures they used? Are they planning to stop practice temporarily? In the 10th question, the participants were asked to write their medical degree and the organization.

\section{Results:}

The survey results are shown in Table 1. A total of 205 participants completed the questionnaires. Most of the responders (99\%) faced a case of COVID-19 in their practice with $62.4 \%$ of cases presented by sudden anosmia Figure 1. Infection control measures followed by $93.7 \%$ of participants with $71.3 \%$ used combinations of face mask, alcohol and face shield in their practice, with only $2 \%$ of them did not fully respond to infection control measures, but to some extent if they faced a case of COVID-19 in their practice. $58.5 \%$ of the participant's regulated patients' times to avoid crowdedness and about $23.4 \%$ of the patients followed the instructions About $53.7 \%$ of the participants do emergent surgeries with $51.7 \%$ planning to stop practice temporarily.

\section{Discussion:}

Otolaryngologists may be the first healthcare providers who deal with patients suspected of COVID-19 and have a higher risk of infection due to the nature of their specialty [7].

Recently it has been found that Covid-19 infection is associated with smell and taste dysfunction. Besides, there have been a rapidly growing number of reports about loss of smell strongly correlates with the increased prevalence of Covid19. Medical discussion boards by surgeons all over the world widely shared a high incidence of patients presenting with anosmia in the absence of other symptoms nowadays. Patients who present with influenza-like symptoms and anosmia are 6-10 times more likely to test positive for Covid-19 infection. Indeed, 59-86\% of outpatient Covid-19 positive patients have self-reported anosmia. Significantly, in Covid-19-positive hospitalized patients also self-reported anosmia has been identified as a common symptom [8-12]. 
A recent report by Yun Jin Kang et al have concluded that one of the early signs of COVID-19 is anosmia even without other upper respiratory infection or otolaryngologic symptoms this coincides with Moein et al who reported a high rate of measured anosmia (98\%) on quantitative analysis of Covid-19 inpatients. Nowadays report has confirmed that anosmia Covid-19 may associate with a milder clinical course and therefore reflect an increase in the prevalence of mild cases of Covid-19 than the severe one and may be due to a decrease of the virus load or its virulence. So proper precautions should be taken by all otolaryngologic centers to protect both patients and staff from infection as it may harbor many asymptomatic patients with COVID-19 [11, 13, 14].

To prevent patients' crowdedness a strict timetable of every patient should be done with a decrease in the total number of patients attending the facility. Patients with chronic otolaryngology diseases and those not requiring urgent otolaryngology consultations should be consulted by phone. Measurement of body temperature for every individual requiring an otolaryngology visit should be done before entering the outpatient clinic $[15,16]$.

It is recommended that fully equipped facilities should be presented to every patient with unknown status of COVID19 who will be examined by otolaryngologists and the correct use of PPE should be promoted[17, 18].

Current evidence nowadays reported that human coronavirus can stay infectious on inanimate surfaces for as long as 9 days. Therefore, the disinfection of surfaces is very important to reduce the viral load and decrease the spread of infection [19]. Elective services and surgeries should be avoided or better to be reduced to reduce the risk of transmission due to people's collection. Emergency patients are assessed and managed according to recent guidelines of infection control measures [20].

\section{Conclusion:}

Sudden anosmia in asymptomatic patients should be taken cautiously as it may be a sign of a mild attack of COVID-19. In order to decrease COVID-19 transmission among otorhinolaryngologists, infection control measures should be used appropriately for their safety and to control the spread of COVID19. Proper uses of PPE are the cornerstone of infection control measures.

\section{Funding}

This research did not receive any specific grant from funding agencies in the public, commercial, or not-for-profit sectors.

\section{Conflict of interest}

None.

\section{References:}

1.Chen, X. and B. Yu, First two months of the 2019 Coronavirus Disease (COVID-19) epidemic in China: realtime surveillance and evaluation with a second derivative model. Global health research and policy, 2020. 5(1): p. 1-9.

2.Organization, W.H., WHO DirectorGeneral's remarks at the media briefing on 2019-Nov on 11 February 2020. World Health Organization, Geneva. Available via https://www. who. int/dg/speeches/detail/whodirector-generals-remarks-at-themedia-briefing-on-2019-Nov-on-11February-2020. Accessed, 2020. 10.

3.Guo, Y.-R., et al., The origin, transmission, and clinical therapies on coronavirus disease 2019 (COVID- 
19) outbreak-an update on the status. Military Medical Research, 2020. 7(1): p. 1-10.

4.Krajewska, J., et al., COVID-19 in otolaryngologist practice: a review of current knowledge. European Archives of Oto-Rhino-Laryngology, 2020: p. 1-13.

5.Hopkins, C., P. Surda, and N. Kumar, Presentation of new-onset anosmia during the COVID-19 pandemic. Rhinology, 2020. 10.

6.Chan, J.Y., E.W. Wong, and W. Lam, Practical aspects of otolaryngologic clinical services during the 2019 novel coronavirus epidemic: an experience in Hong Kong. JAMA Otolaryngology-Head \& Neck Surgery, 2020.

7.Vukkadala, N., et al., COVID-19 and the otolaryngologist: a preliminary evidence-based review. Laryngoscope, 2020.

8.Bénézit, F., et al., Utility of hyposmia and hypogeusia for the diagnosis of COVID-19. The Lancet Infectious Diseases, 2020.

9.Hopkins, C. and N. Kumar, Loss of sense of smell as a marker of COVID19 infection. The Royal College of Surgeons of England: British Rhinological Society, 2020.

10.Lechien, J.R., et al., Olfactory and gustatory dysfunctions as a clinical presentation of mild-to-moderate forms of the coronavirus disease (COVID-19): a multicenter European study. European Archives of OtoRhino-Laryngology, 2020: p. 1-11.

11.Moein, S.T., et al. Smell dysfunction: $a$ biomarker for COVID-19. in the
International forum of allergy \& rhinology. 2020. Wiley Online Library.

12.Yan, C.H., et al. Self-reported olfactory loss associates with outpatient clinical course in COVID19. in International Forum of Allergy \& Rhinology. 2020. Wiley Online Library.

13.Heidari, F., et al., Anosmia as a prominent symptom of COVID-19 infection. Rhinology, 2020. 58(3): p. 302-303.

14.Kang, Y.J., et al., The diagnostic value of detecting sudden smell loss among asymptomatic COVID-19 patients in early-stage: the possible early sign of COVID-19. Auris Nasus Larynx, 2020 .

15.Bann, D.V., et al., Best practice recommendations for pediatric otolaryngology during the COVID-19 pandemic. Otolaryngology-Head and Neck Surgery, 2020. 162(6): p. 783794.

16.Zhao, C., et al., Otolaryngology during COVID-19: Preventive care and precautionary measures. American Journal of Otolaryngology, 2020: p. 102508.

17.Cheng, X., et al., Otolaryngology providers must be alert for patients with mild and asymptomatic COVID19. Otolaryngology-Head and Neck Surgery, 2020: p. 0194599820920649.

18.Givi, B., et al., Safety recommendations for evaluation and surgery of the head and neck during the COVID-19 pandemic. JAMA Otolaryngology-Head \& Neck Surgery, 2020. 
19.Kampf, G., et al., Persistence of coronaviruses on inanimate surfaces and their inactivation with biocidal agents. Journal of Hospital Infection, 2020. 104(3): p. 246-251.

20.Lu, D., et al., Integrated infection control strategy to minimize nosocomial infection of coronavirus disease 2019 among ENT healthcare workers. The Journal of hospital infection, 2020. 104(4): p. 454.

Figure legends

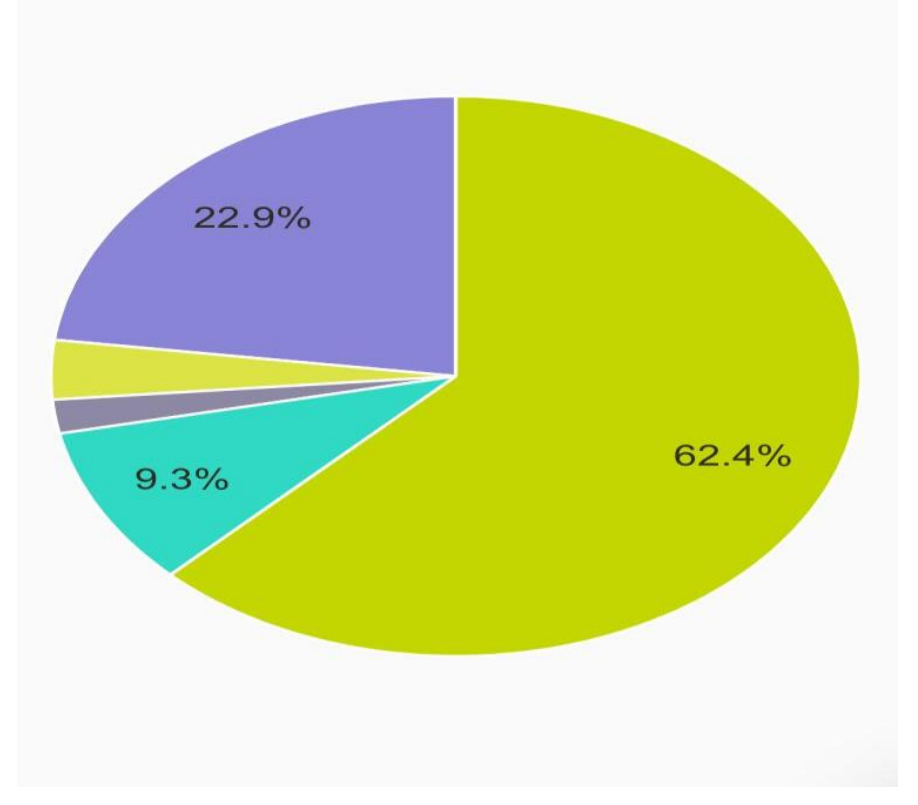

Anosmia

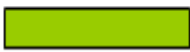

Cough and expectoration

Combinations

Fever

Sore throat

Figure 1. A common manifestation of COVID-19. 


\begin{tabular}{|c|c|c|c|c|c|c|c|}
\hline $\begin{array}{l}\text { 1-Did you face a case } \\
\text { of COVID-19 in your } \\
\text { practice }\end{array}$ & $\begin{array}{c}\text { Yes } \\
203(99 \%)\end{array}$ & $\begin{array}{c}\text { No } \\
2(1 \%)\end{array}$ & & & & & \\
\hline $\begin{array}{l}\text { 2-common } \\
\text { manifestation you } \\
\text { face as a symptom of } \\
\text { COVID-19? }\end{array}$ & $\begin{array}{c}\text { Anosmia } \\
128 \\
(62.4 \%)\end{array}$ & $\begin{array}{c}\text { Sore } \\
\text { throat } \\
19(9.3 \%)\end{array}$ & $\begin{array}{c}\text { cough and } \\
\text { expectorati } \\
\text { on } \\
4(2 \%)\end{array}$ & $\begin{array}{l}\text { Arthralgia } \\
\text { and } \\
\text { myalgia } \\
0(0 \%)\end{array}$ & $\begin{array}{c}\text { Fever } \\
7 \\
(3.4 \%)\end{array}$ & $\begin{array}{l}\text { Runny nose } \\
0(0 \%)\end{array}$ & $\begin{array}{l}\text { Combinations } \\
47(22.9 \%)\end{array}$ \\
\hline $\begin{array}{l}\text { 3-Do you follow all } \\
\text { instructions of } \\
\text { infection control in } \\
\text { your practice? }\end{array}$ & $\begin{array}{c}\text { Yes } \\
192 \\
(93.7 \%)\end{array}$ & $\begin{array}{c}\text { No } \\
13(6.3 \%)\end{array}$ & & & & & \\
\hline $\begin{array}{l}\text { 4-What will you do if } \\
\text { you faced a case of } \\
\text { COVID-19 in your } \\
\text { practice? }\end{array}$ & $\begin{array}{l}\text { Neglect } \\
4(2 \%)\end{array}$ & $\begin{array}{c}\text { Follow } \\
\text { infection } \\
\text { control } \\
\text { measures } \\
160 \\
(78 \%)\end{array}$ & $\begin{array}{c}\text { Other } \\
41(20 \%)\end{array}$ & & & & \\
\hline $\begin{array}{l}\text { 5-Do you regulate } \\
\text { patients' times to } \\
\text { avoid crowdness? }\end{array}$ & $\begin{array}{c}\text { Yes } \\
\\
120 \\
(58.5 \%)\end{array}$ & $\begin{array}{c}\text { No } \\
9(4.4 \%)\end{array}$ & $\begin{array}{c}\text { To some } \\
\text { extent } \\
76(37.1 \%)\end{array}$ & & & & \\
\hline $\begin{array}{l}\text { 6-Do the patients } \\
\text { follow the } \\
\text { instructions? }\end{array}$ & $\begin{array}{c}\text { Yes } \\
48(23.4 \%)\end{array}$ & $\begin{array}{c}\text { No } \\
6(2.9 \%)\end{array}$ & $\begin{array}{c}\text { To some } \\
\text { extent } \\
151 \\
(73.7 \%)\end{array}$ & & & & \\
\hline $\begin{array}{l}7 \text {-What about } \\
\text { surgeries you } \\
\text { practice? }\end{array}$ & $\begin{array}{c}\text { Emergency } \\
\text { only } \\
110 \\
(53.7 \%)\end{array}$ & $\begin{array}{c}\text { All } \\
\text { operation } \\
\text { s with } \\
\text { precautio } \\
\text { ns } \\
65 \\
(31.1 \%)\end{array}$ & 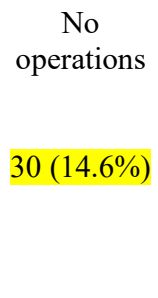 & & & & \\
\hline $\begin{array}{l}\text { 8-What type of safety } \\
\text { measures do you use? }\end{array}$ & $\begin{array}{c}\text { Mask } \\
55(26.8 \%)\end{array}$ & $\begin{array}{l}\text { Face } \\
\text { shield, } \\
2(1 \%)\end{array}$ & $\begin{array}{l}\text { Alcohol } \\
1(0.5 \%)\end{array}$ & $\begin{array}{l}\text { Gown } \\
0(0 \%)\end{array}$ & $\begin{array}{r}\begin{array}{r}\text { Over } \\
\text { head }\end{array} \\
0(0 \%)\end{array}$ & $\begin{array}{l}\text { Gloves } \\
1(0.5 \%)\end{array}$ & $\begin{array}{c}\text { Combinations } \\
146(71.2 \%)\end{array}$ \\
\hline $\begin{array}{l}\text { 9-Are you planning } \\
\text { to stop practice } \\
\text { temporarily? }\end{array}$ & $\begin{array}{c}\text { Yes } \\
106 \\
(51.7 \%)\end{array}$ & $\begin{array}{c}\text { No } \\
99 \\
(48.3 \%)\end{array}$ & & & & & \\
\hline
\end{tabular}

Table 1. An internet-based questionnaire survey. 